\title{
ANALISIS POSITIONING DENGAN MULTI DIMENSIONAL SCALLING (MDS) DAN ANALISIS FAKTOR UNTUK PEMETAAN CITY CAR DI MAKASSAR
}

\author{
Esti Dwi Rinawiyanti, Arbi Hadiyat, Hardi Yanto \\ Jurusan Teknik Industri, Fakultas Teknik, Universitas Surabaya \\ estidwi@staff.ubaya.ac.id
}

\begin{abstract}
ABSTRAK
City car mempunyai permintaan pasar yang cukup tinggi di Makassar. Studi ini dilakukan untuk melakukan pemetaan city car di Makassar dengan menggunakan Multidimensional Scalling (MDS) dan analisis factor karena masih sedikit studi mengenai positioning city car di Makassar. Penelitian ini menggunakan data sekunder dan data primer. Data sekunder diperoleh melalui institusi terkait dan melalui internet, sedangkan data primer dikumpulkan melalui wawancara dengan pemilik dealer mobil di Makassar dan pembagian kuisioner kepada 100 responden konsumen pengguna city car di Makassar. Berdasarkan analisa tingkat kepentingan didapatkan tiga variabel yang memperoleh nilai rata-rata tertinggi untuk konsumen penggunacity car. Variabel tersebut yaitu keamanan berkendara, kenyamanan berkendara, dan garansi. Dari analisa faktor diperoleh nama-nama untuk dimensi yang digunakan pada MDS, yaitu dimensi $1=$ performa perusahaan pemegang merek, dimensi 2=performa mobil yang ditawarkan, dan dimensi 3= penawaran promosi.
\end{abstract}

Kata kunci: pemetaan, analisis positioning, multidimensional scalling, city car

\begin{abstract}
City car is one type of prefered car by consumers because of its small dimension, its agility, and its fuel efficiency. Similarly in Makassar, as the fifth largest city in Indonesia and the trading center in Eastern Indonesia, city car has high market demand. This study was conducted to map city car's positioning in Makassar by using Multidimensional Scalling (MDS) and factor analysis. Although some previous studies have used MDS to analyze the city car's positioning, most of them was done in big cities in Java Island and there is still little study that analyze the positioning of city car in Makassar. This study used secondary data and primary data. Secondary data was obtained through related institutions and internet, while primary data was collected through interviews with car dealer owners in Makassar and the distribution of questionnaires to 100 city car consumers in Makassar. Based on the analysis of the importance level there were three variables with the highest average value from city car consumers, namely driving safety, driving comfort, and warranty. The factor analysis was used to identify the names for dimensions used on MDS, i.e. dimension 1 = performance of the company holder of the brand, dimension 2 = the performance of the car offered, and dimension 3 = promotional offer.
\end{abstract}

Keywords: mapping, positioning analysis, multidimensional scalling, city car 


\section{Esti Dwi Rinawiyanti}

\section{Arbi Hadiyat}

Hardi Yanto

PENDAHULUAN

Mobil merupakan kendaraan yang menjadi sarana transportasi utama untuk sebagian besar orang di Indonesia di samping sepeda motor. Selain memberikan perlindungan dari cuaca baik panas terik matahari maupun dinginnya hujan mobil juga memberi kenyamanan bagi penggunanya karena posisi berkendara yang lebih santai. Tingginya pertumbuhan ekonomi berdampak pada penjualan mobil di Indonesia yang terus tumbuh. (Rakyat Sulsel, 2013). Peningkatan penjualan kendaraan roda empat juga terjadi di Makassar. Sebagai satu dari lima kota terbesar di Indonesia, Makassar mempunyai lokasi yang strategis karena tepat di tengah Indonesia dan merupakan hub atau pusat perdagangan di Indonesia, selain Jakarta. Makassar merupakan pusat ekonomi tersebesar di kawasan Indonesia Bagian Timur dengan populasi mencapai 1,8 juta orang. Pertumbuhan ekonomi Makassar pun merupakan yang tertinggi di Indonesia, sebesar 9,23\% di tahun 2014 (Kompas, 2015). Data Gabungan Industri Kendaraan Bermotor Indonesia (Gaikindo) menunjukkan bahwa penjualan kendaraan roda empat di Makassar tahun 2013 tumbuh sebesar 13\% atau sekitar 2.768 unit. Tahun 2014 pertumbuhan kendaraan di Makassar 11\%, lebih besar dari kota-kota lain di Indonesia(Dapur Pacu, 2014).

City car adalah satu dari sekian model mobil yang memiliki jumlah peminat tinggi setelah low MPV dan mobil murah ramah lingkungan (low cost green car/LCGC) (Otoasia, 2015). Hal tersebut dikarenakan beberapa faktor, antara lain efisiensi dan kenyamanan interior dan handling, dimensi kecil yang memungkinkan mobil ini bermanuver lincah dan lebih mudah dikendarai terutama ketika mencari parkir. Faktor yang membuat city car lebih nyaman dikendarai daripada membawa mobil berdimensi besar (Liputan 6, 2014). Disamping itu city car dinilai lebih ekonomis dan efisien dalam penggunaan bahan bakar, sehingga diprediksikan masih akan tumbuh sekitar 5-10\% di tahun 2015 dari penjualan nasional tahun 2014 sebesar 4.000 per bulan (Otomotif Bisnis, 2015). Berdasarkan data di internet, informasi dari penelitian sebelumnya, dan dari survey awal terdapat 10 merek city car yang paling diminati oleh konsumen khususnya di Makassar. Merek tersebutdiantaranya Toyota Yaris, Honda Jazz, Mazda 2, Ford Fiesta, Daihatsu Sirion, Nissan March, Suzuki Swift, Mitsubishi Mirage, KIA RIO, dan Hyundai Grand Avega. Banyaknya merek city car yang beredar di pasar mobil menyebabkan persaingan city car di Makassar cukup ketat. Masing-masing merek mobil dengan kelebihan dan keunggulan yang ditawarkan memiliki peluang untuk bersaing dan bahkan menguasai pasar city car di Makassar. Berdasarkan pertimbangan tersebut, maka pemetaan posisi city car di Makassar dirasa perlu. Penelitian ini dilakukan untuk mengetahui pemetaan positioning city car di Makassar dengan menggunakan MDS (Multidimensional Scaling). Nama dimensi yang digunakan dalam MDS didapatkan dari 
analisa faktor. Hasil dari penelitian ini dapat menjadi acuan bagi produsen city car untuk merancang strategi bauran pemasaran yang tepat dan sesuai sasaran.

Penelitian untuk mengetahui positioning suatu produk/merek yang dilakukan dengan menggunakan MDS sudah banyak dilakukan. Penelitian Hardianto (2006) mengenai posisi produk city car di Yogyakarta dilakukan pada tiga merek city car, yaitu Honda Jazz, Toyota Yaris, Suzuki Swift, dan Chevrolet Aveo. Penggunaan MDS juga digunakan untuk analisa peta persepsi konsumen pada kelima merek city car di Semarang: Honda, Toyota, Mazda, Suzuki, dan Nissan (Ni Luh, 2011). Selain itu, Tiara dkk (2014) menggunakan MDS untuk membandingkan positioning Honda Jazz di antara sepuluh merek city car di Surabaya (Toyota Yaris, Suzuki Swift, Suzuki Splash, Ford Fiesta, Kia Picanto, Hyundai i10, Nissan March, Chevrolet Aveo dan Chevrolet Spark). Putus Agus (2011) melakukan penelitian di kota-kota besar di Pulau Jawa, namun masih sedikit penelitian yang diadakan di luar Pulau Jawa. Penelitian ini memberikan kontribusi dan mengisi kekosongan yang ada dengan memberikan informasi pemetaan city car di Makassar.

\section{KAJIAN PUSTAKA}

Positioning merupakan hal yang harus ditentukan terlebih dahulu sebelum merancang bauran pemasaran, bahkan positioning menjadi dasar bagi strategi selanjutnya. Positioning merupakan strategi komunikasi yang berusaha menempatkan suatu produk atau merek pada bagian pasar tertentu sehingga dapat diterima oleh konsumennya secara lebih baik daripada merek produk lain (Kotler dan Armstrong, 2012). Produk juga dapat dipisahkan atau dibedakan dari merek yang lain dengan cara menentukan positioning.

Salah satu metode yang bisa digunakan untuk menentukan positioning suatu produk atau merek ialah Multidimensional Scaling (MDS) atau dikenal juga sebagai pemetaan persepsi, yang merupakan suatu prosedur untuk menentukan citra dari suatu obyek (perusahaan, produk, ide, atau obyek lain yang terkait dengan persepsi umum). Tujuan dari MDS adalah untuk mengubah penilaian konsumen dari kesamaan secara keseluruhan atau preferensi (preferensi terhadap suatu toko atau merek) dalam jarak yang digambarkan dalam ruang multidimensi (Hair, Black, Babin \& Andersen, 2010). Terdapat tiga langkah dasar yang dilakukan dengan MDS, yaitu: (1) Mengumpulkan ukuran kesamaan atau preferensi dari seluruh obyek yang akan diteliti, (2) Menggunakan teknik MDS untuk memperkirakan posisi dari setiap obyek dalam ruang multidimensi, dan (3) Mengidentifikasi dan menginterpretasikan sumbu dari ruang dimensi dalam hal atribut persepsi dan atau tujuan. Ada dua metode dasar yang dapat digunakan dalam melakukan MDS, yaitu: (1) Pendekatan atribut dengan mengumpulkan persepsi masyarakat mengenai atribut-atribut 


\section{Esti Dwi Rinawiyanti}

\section{Arbi Hadiyat}

\section{Hardi Yanto}

tertentu yang dimiliki oleh obyek-obyek tertentu yang merupakan obyek penelitian ini; dan (2) Pendekatan kemiripan/ketidakmiripan berdasarkan tingkat kemiripan/ketidakmiripan obyek-obyek yang menjadi obyek penelitian. Similarity(kemiripan) yaitu jika semakin kecil nilai jaraknya, menunjukkan bahwa objeknya lebih mirip, sedangkan dissimilarity (ketakmiripan) yaitu bila semakin besar nilai jaraknya, menunjukkan bahwa objeknya semakin tak mirip (Ginanjar, 2008).

Pemberian nama pada dimensi-dimensi tersebut dapat dilakukan dengan beberapa pendekatan. Pendekatan-pendekatan tersebut menurut Raza Rabbani \& Nabi (2013) adalah sebagai berikut: (1) Pendekatan pertama adalah dengan meminta setiap responden untuk memberikan penilaian terhadap dimensi-dimensi tersebut. Peneliti kemudian menghubungkan dan menilai dimensi-dimensi yang disebutkan responden yang sesuai dengan hasil MDS, (2) Pendekatan kedua adalah dengan meminta pihak perusahaan memberikan nama dimensi-dimensi tersebut berdasarkan pengalaman dan pengamatan pada hasil MDS tersebut, (3) Pendekatan ketiga adalah dengan menghubungkan dimensi-dimensi tersebut dengan karakteristik spesial dari obyek penelitian tersebut.

\section{METODE PENELITIAN}

Penelitian ini menggunakan dua jenis data, yaitu data primer dan sekunder. Sumber data sekunder pada penelitian ini didapatkan dari Dinas Perhubungan Kota Makassar dan internet, sedangkan data primer diperoleh dari wawancara langsung dengan dealer city car dan survey. Penelitian didahului dengan survey awal, baik wawancara maupun penyebaran kuisioner kepada 20 orang responden yang merupakan konsumen pengguna city car di Makassar. Selanjutnya penyusunan kuisioner untuk menilai persepsi konsumen terhadap tingkat kemiripan mobil-mobil jenis city car, sehingga didapatkan sepulun (10) merekcity car yang paling diminati konsumen. Pada bagian ini responden memberikan nilai pada tingkat kemiripan mobil tersebut dengan menggunakan skala 1-6 dimana 1 adalah sangat tidak mirip dan 6 adalah sangat mirip, setelah itu responden menyebutkan hal-hal yang menjadi pertimbangannya dalam memberikan penilaian tersebut. Selain itu, hasil survey awal mengidentifikasi beberapa variabel/atribut yang dipentingkan konsumen dalam memilih city car, seperti desain, harga, efisiensi bahan bakar, kapasitas, dan kenyamanan. Selanjutnya variabel tersebut dikembangkan ke dalam delapan dimensi bauran pemasaran untuk analisa tingkat kepentingan. Digunakan delapan (8) dimensi bauran pemasaran yang merupakan strategi pemasaran jasa dengan pertimbangan bahwa dealer mobil adalah pihak yang berhadapan langsung dengan konsumen. Dengan demikian, selain empat $P$ 


\section{Jurnal Manajemen Teori dan Terapan \\ Tahun 11. No. 1, April 2018}

dasar (product, price, place, promotion), mereka juga harus mengimplementasikan P yang lain (people, process, physical evidence, dan productivity and quality) untuk memberikan jasa yang memuaskan bagi konsumen, yang melengkapi produk mobil yang ditawarkan.

Populasi pada penelitian ini adalah konsumen yang memiliki dan menggunakan kendaraan roda empat (mobil) di Makassar. Teknik sampling dilakukan dengan non probability yaitu dengan cara purposive sampling, dimana sampel dipilih berdasarkan pada pertimbangan bahwa unit atau unsur penarikan sampel tersebut akan dapat membantu menjawab pertanyaan penelitian yang sedang dikerjakan. Penentuan sampel menggunakan rumus Slovin sebagai berikut: $\mathrm{n}=\frac{N}{1+N e^{2}}$, dimana: $\mathrm{n}=$ jumlah minimal sampel yang dibutuhkan, $\mathrm{N}=$ jumlah populasi, dan e= error bound yang ditoleransisebesar 10\%dengan pertimbangan pada keterbatasan dana dan waktu yang dimiliki (Cochran, 1977). Dengan demikian sampel minimal yang dibutuhkan yaitu:

$$
n=\frac{N}{1+N e^{2}} \rightarrow n=\frac{102804}{1+102804(0,1)^{2}}=99,903 \cong 100
$$

Jumlah populasi (angka 102.804) adalah jumlah kendaraan mobil penumpang di Makassar pada tahun 2010. Data tersebut diperoleh dari Dinas Perhubungan Kota Makassar. Data tersebut tidak memberikan informasi secara jelas mengenai berapa banyak jumlah city car di Makassar, Dinas Perhubungan hanya mencatat mobil jenis city car sebagai mobil penumpang sehingga pada perhitungan ini peneliti hanya dapat menggunakan data tersebut karena keterbatasan informasi. Dari perhitungan diketahui jumlah sampel yang dibutuhkan ialah 100 responden. Pengolahan data menggunakan bantuan program SPSS version 18.

\section{ANALISA DATA}

Hasil pengolahan data yang dilakukan terhadap data dari survey dijelaskan sebagai berikut.

\section{Analisa Deskriptif}

Analisa deskriptif dilakukan untuk mendapatkan gambaran profil dari responden dengan data sebagai berikut. Pengolahan data dari 100 responden ditampilkan di tabel 1. Dari tabel 1 dapat diketahui bahwa konsumen pengguna city car di Makassar mayoritas adalah lakilaki, berumur 21-39 tahun, sebagian besar pengusaha/wiraswasta dengan pendapatan per bulan lebih dari 6 juta rupiah. Merek city car yang dimiliki terbanyak adalah Toyota dan Honda dan lama memiliki mobil lebih dari 1 tahun. 


\section{Esti Dwi Rinawiyanti}

\section{Arbi Hadiyat}

Hardi Yanto

\section{Analisa Tingkat Kepentingan}

Berikut merupakan hasil dari pengumpulan data tingkat kepentingan konsumen pengguna city car di Makassar. Responden diminta untuk memberikan penilaian pada variabelvariabel yang dibuat berdasarkan dari bauran pemasaran 8P dengan memilih dari nilai 1-6 dimana 1 adalah sangat tidak penting dan 6 adalah sangat penting. Variabel yang digunakan pada kuisioner merupakan hasil dari survey awal dan wawancara dengan pemilik dealer mobil di Makassar. Dengan mengetahui tingkat kepentingan tersebut, dapat diketahui pula variabel apa saja yang dipentingkan oleh konsumen pengguna city car sehingga dapat membantu dalam perancangan strategi pemasaran untuk mobil city car di Makassar.

Tabel 1.

Profil Konsumen Pengguna City Car di Makassar

\begin{tabular}{ll}
\hline \multicolumn{1}{c}{ Pertanyaan } & \multicolumn{1}{c}{ Jawaban (mayoritas) } \\
\hline Jenis kelamin & laki-laki (64\%) \\
Usia saat ini & 21-29 tahun (39\%), 30-39 tahun (39\%) \\
Pekerjaan saat ini & pengusaha/wiraswasta (53\%), pegawai swasta/negeri (23\%) \\
Pendapatan per bulan & $6.000 .001-9.000 .000(38 \%)$, lebih dari $9.000 .000(36 \%)$ \\
Merek city caryang dimiliki & Toyota (28\%), Honda (25\%) \\
Lama memiliki mobil & 2 tahun (38\%), 1 tahun (24\%) \\
\hline
\end{tabular}

Hasil pengumpulan data pada bagian tingkat kepentingan tersebut dicari rata-ratanya dan kemudian dikelompokkan untuk mempermudah dilakukannya analisa sebagai berikut:

- $1,00-2,67$ : tingkat kepentingan rendah

- 2,68-4,33 : tingkat kepentingan sedang

- 4,34-6,00 : tingkat kepentingan tinggi

Hasil pengolahan data terhadap tingkat kepentingan konsumen pengguna city car dapat dilihat pada tabel 2.

Pada tabel 2 dapat dilihat bahwa tiga variabel yang memiliki nilai rata-rata tertinggi adalah keamanan berkendara $(5,77)$, kenyamanan berkendara $(5,76)$, dan garansi $(5,69)$. Hal ini menunjukkan bahwa ketiga variabel tersebut merupakan variabel yang paling dipentingkan oleh konsumen pengguna city car di Makassar. 
Tabel 2.

Analisis Tingkat Kepentingan Konsumen Pengguna City Car di Makassar

\begin{tabular}{|c|c|c|c|c|}
\hline Dimensi & Variabel & $\begin{array}{c}\text { Rata- } \\
\text { rata } \\
\text { Variabel }\end{array}$ & $\begin{array}{l}\text { Tingkat } \\
\text { Kepentingan }\end{array}$ & $\begin{array}{l}\text { Rata- } \\
\text { rata } \\
\text { Dimensi }\end{array}$ \\
\hline Product & Model dan desain & 5,34 & Tinggi & 5,23 \\
\hline \multirow[t]{3}{*}{ elements } & Mesin & 5,41 & Tinggi & \\
\hline & Pilihan warna & 4,65 & Tinggi & \\
\hline & Fasilitas Interior & 5,51 & Tinggi & \\
\hline Price and & Harga yang bersaing & 5,52 & Tinggi & 5,61 \\
\hline other cost of & Bonus atau diskon & 5,60 & Tinggi & \\
\hline \multirow[t]{2}{*}{ service } & Garansi & 5,69 & Tinggi & \\
\hline & Servis & 5,61 & Tinggi & \\
\hline \multirow[t]{2}{*}{$\begin{array}{l}\text { Place and } \\
\text { time }\end{array}$} & $\begin{array}{l}\text { Ketersediaan produk di dealer } \\
\text { resmi }\end{array}$ & 5,07 & Tinggi & 5,15 \\
\hline & $\begin{array}{l}\text { Ketersediaan suku cadang di } \\
\text { bengkel resmi }\end{array}$ & 5,22 & Tinggi & \\
\hline \multirow[t]{3}{*}{ Process } & Pilihan cara pembayaran & 4,75 & Tinggi & 4,91 \\
\hline & Kemudahan memesan produk & 4,96 & Tinggi & \\
\hline & Kemudahan membeli produk & 5,01 & Tinggi & \\
\hline Productivity & Penggunaan bahan bakar irit & 5,64 & Tinggi & 5,52 \\
\hline \multirow[t]{4}{*}{ and quality } & Kapasitas penumpang banyak & 4,86 & Tinggi & \\
\hline & Perawatan & 5,56 & Tinggi & \\
\hline & Kenyamanan berkendara & 5,76 & Tinggi & \\
\hline & Keamanan berkendara & 5,77 & Tinggi & \\
\hline \multirow[t]{3}{*}{ People } & Sales yang ramah dan informatif & 4,53 & Tinggi & 4,62 \\
\hline & Kecepatan pelayanan & 4,62 & Tinggi & \\
\hline & Ketepatan pelayanan & 4,72 & Tinggi & \\
\hline Promotion & Brand Image & 5,21 & Tinggi & 5,18 \\
\hline $\begin{array}{l}\text { and } \\
\text { education }\end{array}$ & Promosi & 5,14 & Tinggi & \\
\hline Physical & Showroom & 5,04 & Tinggi & 5,21 \\
\hline evidence & Bengkel & 5,37 & Tinggi & \\
\hline
\end{tabular}




\section{Esti Dwi Rinawiyanti}

\section{Arbi Hadiyat}

Hardi Yanto

Dimensi yang paling dipentingkan oleh konsumen pengguna city car adalah dimensi price and other cost of service (nilai rata-rata dimensi5,61) yang meliputi harga yang bersaing, bonus atau diskon, garansi, dan servis. Selain itu, dimensi productivity and quality juga mendapatkan nilai rata-rata dimensi tertinggi $(5,52)$ yang terdiri dari penggunaan bahan bakar irit, kapasitas penumpang banyak, perawatan, kenyamanan berkendara, dan keamanan berkendara. Dimensi dengan tingkat kepentingan terendah adalah dimensi people (nilai rata-ratadimensi 4,62) yang mencakup sales yang ramah dan informatif, kecepatan pelayanan, dan ketepatan pelayanan. Secara keseluruhan konsumen pengguna city car di Makassar dapat dikatakan memiliki tingkat kepentingan yang tinggi pada semua variabel yang ada dan dapat langsung terlihat dari tabel di atas dimana semua variabel-variabel yang ada memperoleh nilai tinggi.

\section{Analisa Pemetaan}

Untuk melakukan analisa pemetaan menggunakanMDSpertama-tama harus dibuat suatu matriks tingkat kemiripan mobil. Matriks ini dibuat berdasarkan hasil pengumpulan data dimana responden diminta memberikan nilai 1-6 untuk 1 adalah sangat tidak mirip dan 6 adalah sangat mirip. Kemudian nilai-nilai tersebut dijumlahkan untuk melihat manakah yang memiliki nilai tertinggi yang kemudian diberi peringkat/rank sesuai dengan nilai-nilai tersebut.

Terdapat 10 merek terpilih yang merupakan hasil dari survei awal (dipilih 10 merek teratas yang paling diketahui oleh responden). Mobil-mobil yang dipilih adalah mobil-mobil city car yang sudah banyak digunakan dan dikenal oleh masyarakat di Makassar dan memiliki kelas, segmen, dan target pasar yang sama. Kelas yang sama adalah karena mobil tersebut sama-sama tergolong city car, segmen dan target pasarnya pun adalah sama yaitu mahasiswa, pelajar, eksekutif muda, dan keluarga.Mobil-mobil tersebut adalah Toyota Yaris, Honda Jazz, Mazda 2, Ford Fiesta, Daihatsu Sirion, Nissan March, Suzuki Swift, Mitsubishi Mirage, KIA RIO, dan Hyundai Grand Avega.Merek-merek tersebut juga digunakan di penelitian-penelitian sebelumnya. Hasil pengumpulan data dapat dilihat pada tabel 3.

Contoh cara perhitungan nilai total adalah sebagai berikut:

KIA RIO - Hyundai Grand Avega $=\left(6^{*} 28\right)+\left(5^{*} 20\right)+\left(4^{*} 22\right)+\left(3^{*} 14\right)+(2 * 16)+(1 * 0)=$ $168+100+88+42+32+0=430$. 
Tabel 3.

Hasil Data MDS Konsumen Pengguna City Cardi Makassar

\begin{tabular}{|c|c|c|c|c|c|c|c|c|c|c|}
\hline \multirow{2}{*}{$\frac{\text { No }}{1}$} & \multicolumn{2}{|c|}{ Mobil } & \multirow{2}{*}{$\begin{array}{l}\text { nilai } \\
6 \\
40\end{array}$} & \multirow{2}{*}{$\begin{array}{c}\text { nilai } \\
5 \\
25\end{array}$} & \multirow{2}{*}{$\begin{array}{c}\text { nilai } \\
4 \\
16\end{array}$} & \multirow{2}{*}{$\begin{array}{c}\text { nilai } \\
3 \\
6\end{array}$} & \multirow{2}{*}{$\begin{array}{c}\text { nilai } \\
2 \\
9\end{array}$} & \multirow{2}{*}{$\begin{array}{c}\text { nilai } \\
1 \\
4\end{array}$} & \multirow{2}{*}{$\begin{array}{c}\text { Total } \\
9\end{array}$} & \multirow{2}{*}{$\begin{array}{c}\text { Rank } \\
2\end{array}$} \\
\hline & Toyota Yaris & Honda Jazz & & & & & & & & \\
\hline 2 & Toyota Yaris & Mazda 2 & 38 & 29 & 22 & 4 & 4 & 3 & 84 & 1 \\
\hline 3 & Toyota Yaris & Ford Fiesta & 26 & 16 & 23 & 18 & 3 & 4 & 12 & 6 \\
\hline 4 & Toyota Yaris & Daihatsu Sirion & 0 & 1 & 40 & 30 & 9 & 10 & 03 & 30 \\
\hline 5 & Toyota Yaris & Nissan March & 2 & 10 & 54 & 23 & 7 & 4 & 65 & 14 \\
\hline 6 & Toyota Yaris & Suzuki Swift & 0 & 29 & 51 & 11 & 5 & 4 & 96 & 8 \\
\hline 7 & Toyota Yaris & $\begin{array}{l}\text { Mitsubishi } \\
\text { Mirage }\end{array}$ & 0 & 16 & 27 & 36 & 8 & 3 & 35 & 21 \\
\hline 8 & Toyota Yaris & KIA Rio & 6 & 1 & 26 & 42 & 21 & 4 & 17 & 25 \\
\hline 9 & Toyota Yaris & $\begin{array}{c}\text { Hyundai Grand } \\
\text { Avega }\end{array}$ & 1 & 9 & 26 & 31 & 24 & 9 & 05 & 29 \\
\hline 10 & Honda Jazz & Mazda 2 & 20 & 37 & 19 & 14 & 8 & 2 & 41 & 3 \\
\hline 11 & Honda Jazz & Ford Fiesta & 31 & 19 & 23 & 9 & 14 & 4 & 32 & 4 \\
\hline 12 & Honda Jazz & Daihatsu Sirion & 0 & 5 & 20 & 42 & 21 & 2 & 85 & 33 \\
\hline 13 & Honda Jazz & Nissan March & 0 & 3 & 27 & 45 & 18 & 7 & 01 & 32 \\
\hline 14 & Honda Jazz & Suzuki Swift & 0 & 8 & 44 & 29 & 17 & 2 & 39 & 20 \\
\hline 15 & Honda Jazz & $\begin{array}{l}\text { Mitsubishi } \\
\text { Mirage }\end{array}$ & 1 & 6 & 27 & 29 & 33 & 4 & 301 & 31 \\
\hline 16 & Honda Jazz & KIA Rio & 8 & 3 & 28 & 39 & 20 & 2 & 334 & 22 \\
\hline 17 & Honda Jazz & $\begin{array}{c}\text { Hyundai Grand } \\
\text { Avega }\end{array}$ & 7 & 13 & 19 & 33 & 24 & 4 & 334 & 23 \\
\hline 18 & Mazda 2 & Ford Fiesta & 13 & 19 & 35 & 17 & 15 & 1 & 395 & 9 \\
\hline 19 & Mazda 2 & Daihatsu Sirion & 0 & 7 & 23 & 45 & 25 & 0 & 312 & 28 \\
\hline 20 & Mazda 2 & Nissan March & 0 & 19 & 39 & 28 & 9 & 5 & 358 & 16 \\
\hline 21 & Mazda 2 & Suzuki Swift & 0 & 15 & 60 & 19 & 5 & 1 & 383 & 11 \\
\hline 22 & Mazda 2 & $\begin{array}{l}\text { Mitsubishi } \\
\text { Mirage }\end{array}$ & 0 & 1 & 32 & 6 & 9 & 2 & 1 & 15 \\
\hline 23 & Mazda 2 & KIA Rio & 2 & 4 & 27 & 39 & 27 & 1 & 312 & 27 \\
\hline 24 & Mazda 2 & $\begin{array}{c}\text { Hyundai Grand } \\
\text { Avega }\end{array}$ & 1 & 12 & 24 & 36 & 25 & 2 & 322 & 24 \\
\hline
\end{tabular}


Esti Dwi Rinawiyanti

\section{Arbi Hadiyat}

Hardi Yanto

\begin{tabular}{|c|c|c|c|c|c|c|c|c|c|c|}
\hline 25 & Ford Fiesta & Daihatsu Sirion & 0 & 3 & 15 & 33 & 37 & & 260 & 6 \\
\hline 26 & Ford Fiesta & Nissan March & 0 & 6 & 13 & 43 & 33 & 5 & 2 & 4 \\
\hline 27 & Ford Fiesta & Suzuki Swift & 0 & 2 & 14 & 45 & 31 & 8 & 271 & 35 \\
\hline \multirow[t]{2}{*}{28} & Ford Fiesta & Mitsubishi & 0 & 6 & 10 & 30 & 42 & 12 & 256 & 38 \\
\hline & & Mirage & & & & & & & & \\
\hline 29 & Ford Fiesta & KIA Rio & 3 & 21 & 50 & 15 & 11 & 0 & 390 & 10 \\
\hline \multirow[t]{2}{*}{30} & Ford Fiesta & Hyundai Grand & 5 & 37 & 34 & 12 & 12 & 0 & 411 & 7 \\
\hline & & Avega & & & & & & & & \\
\hline 31 & Daihatsu Sirion & Nissan March & 1 & 13 & 25 & 31 & 22 & 8 & 316 & 6 \\
\hline 32 & Daihatsu Sirion & Suzuki Swift & 0 & 16 & 33 & 32 & 13 & 6 & 340 & 8 \\
\hline 33 & Daihatsu Sirion & Mitsubish Mirage & 0 & 15 & 32 & 38 & 8 & 7 & 340 & 19 \\
\hline 34 & Daihatsu Sirion & KIA Rio & 2 & 6 & 9 & 13 & 60 & 10 & 247 & 45 \\
\hline \multirow[t]{2}{*}{35} & Daihatsu Sirion & Hyundai Grand & 0 & 6 & 11 & 15 & 57 & 11 & 244 & 43 \\
\hline & & Avega & & & & & & & & \\
\hline 36 & Nissan March & Suzuki Swift & 1 & 20 & 48 & 15 & 10 & 6 & 369 & 13 \\
\hline \multirow[t]{2}{*}{37} & Nissan March & Mitsubishi & 2 & 23 & 42 & 24 & 3 & 6 & 379 & 2 \\
\hline & & Mirage & & & & & & & & \\
\hline 38 & Nissan March & KIA Rio & 2 & 0 & 16 & 24 & 50 & 8 & 256 & 37 \\
\hline \multirow[t]{2}{*}{39} & Nissan March & Hyundai Grand & 0 & 4 & 8 & 26 & 60 & 2 & 252 & 41 \\
\hline & & Avega & & & & & & & & \\
\hline \multirow[t]{2}{*}{40} & Suzuki Swift & Mitsubishi & 0 & 11 & 51 & 20 & 18 & 0 & 355 & 17 \\
\hline & & Mirage & & & & & & & & \\
\hline 41 & Suzuki Swift & KIA Rio & 2 & 4 & 7 & 27 & 49 & 11 & 250 & 42 \\
\hline \multirow[t]{2}{*}{42} & Suzuki Swift & Hyundai Grand & 0 & 3 & 6 & 37 & 49 & 5 & 253 & 39 \\
\hline & & Avega & & & & & & & & \\
\hline \multirow[t]{2}{*}{43} & Mitsubish & KIA Rio & 0 & 3 & 8 & 27 & 56 & 6 & 246 & 44 \\
\hline & Mirage & & & & & & & & & \\
\hline \multirow[t]{2}{*}{44} & Mitsubish & Hyundai Grand & 0 & 5 & 13 & 20 & 53 & 9 & 252 & 40 \\
\hline & Mirage & Avega & & & & & & & & \\
\hline \multirow[t]{2}{*}{45} & KIA Rio & Hyundai Grand & 28 & 20 & 22 & 14 & 16 & 0 & 430 & 5 \\
\hline & & Avega & & & & & & & & \\
\hline
\end{tabular}

Pemberian rank didasarkan pada total nilai. Mobil-mobil yang memiliki nilai total terbesar berarti bahwa mobil tersebut adalah yang paling mirip. Bila, ada mobil-mobil yang memiliki nilai yang sama maka akan dilihat mobil-mobil mana yang memiliki jumlah nilai 6 (sangat mirip) yang paling banyak, mobil-mobil yang memiliki jumlah nilai 6 (sangat mirip) yang paling banyak yang mendapatkan peringkat yang lebih tinggi. Apabila masih terjadi 
persamaan pada jumlah nilai 6 yang dimiliki maka akan dilihat jumlah nilai 5 , dan bila masih terjadi persamaan juga akan dilihat jumlah nilai 4 dan seterusnya.

Data yang telah terkumpul berikutnya digunakan untuk membuat matriks tingkat kemiripan mobil-mobil menurut konsumen pengguna city caryang dapat dilihat pada tabel 4. Pada matriks tersebut, mobil-mobil tersebut diurutkan sesuai tingkat kemiripannya. Konsumen pengguna city car menganggap Toyota Yaris dan Mazda 2 sebagai mobil yang paling mirip berdasarkan survei yang telah dilakukan sehingga memperoleh peringkat atau rank 1. Semakin tinggi peringkat atau rank mobil-mobil tersebut menunjukkan bahwa mobil-mobil tersebut semakin tidak mirip.

Setelah terbentuk matriks seperti tabel 4, selanjutnya dilakukan pengujian stress untuk mengetahui jumlah dimensi yang dapat digunakan dalam multidimensional scaling ini. Pengujian stress dimulai dengan dimensi awal n-1 dimana $n$ adalah jumlah mobil yang ada, dalam kasus ini $n=10$ karena terdapat 10 mobil. Hasil pengujian stress seperti di gambar 1 menunjukkan bahwa dimensi tersebut dapat direduksi menjadi lima dimensi karena nilai stress saat menggunakan lima dimensi adalah yang terkecil. Dimensi ini kemudian diuji lagi untuk mengetahui apakah masih dapat direduksi lagi menjadi lebih sedikit.

Tabel 4.

Matriks Tingkat Kemiripan City Car di Makassar

\begin{tabular}{|c|r|r|r|c|c|c|c|c|c|c|}
\hline & Toyota & Honda & Mazda & Ford & Daihatsu & Nissan & Suzuki & Mitusibishi & Kia & Hyundai \\
\hline Toyota & & - & - & - & - & - & - & - & - & - \\
\hline Honda & 2 & & - & - & - & - & - & - & - & - \\
\hline Mazda & 1 & 3 & & - & - & - & - & - & - & - \\
\hline Ford & 6 & 4 & 9 & & - & - & - & - & & - \\
\hline Daihatsu & 30 & 33 & 28 & 36 & & - & - & - & - & - \\
\hline Nissan & 14 & 32 & 16 & 34 & 26 & & - & - & - & - \\
\hline Suzuki & 8 & 20 & 11 & 35 & 18 & 13 & & - & - & - \\
\hline Mitusibishi & 21 & 31 & 15 & 38 & 19 & 12 & 17 & & - & - \\
\hline Kia & 25 & 22 & 27 & 10 & 45 & 37 & 42 & 44 & & - \\
\hline Hyundai & 29 & 23 & 24 & 7 & 43 & 41 & 39 & 40 & 5 \\
\hline
\end{tabular}

Oleh karena itu, pengujian stress sekali lagi dilakukan untuk mengetahui apakah dimensi tersebut masih dapat direduksi atau harus menggunakan lima dimensi. Ternyata setelah dilakukan pengujian stress sekali lagi diketahui bahwa dimensi tersebut masih dapat direduksi sehingga sisa empat dimensi. Pengujian stress kembali dilakukan pada empat dimensi tersebut untuk mengetahui apakah dimensi yang ada masih dapat direduksi. Hasil akhir dari pengujian stress menunjukkan bahwa dimensi yang dapat digunakan adalah tiga 


\section{Esti Dwi Rinawiyanti}

\section{Arbi Hadiyat}

\section{Hardi Yanto}

dimensi, tetapi nilai stress dua dimensi lebih tinggi daripada nilai stress tiga dimensi. Oleh karena itu, analisa selanjutnya menggunakan dua dimensi. Hasil pengujian dimensi dapat dilihat di gambar 1 .

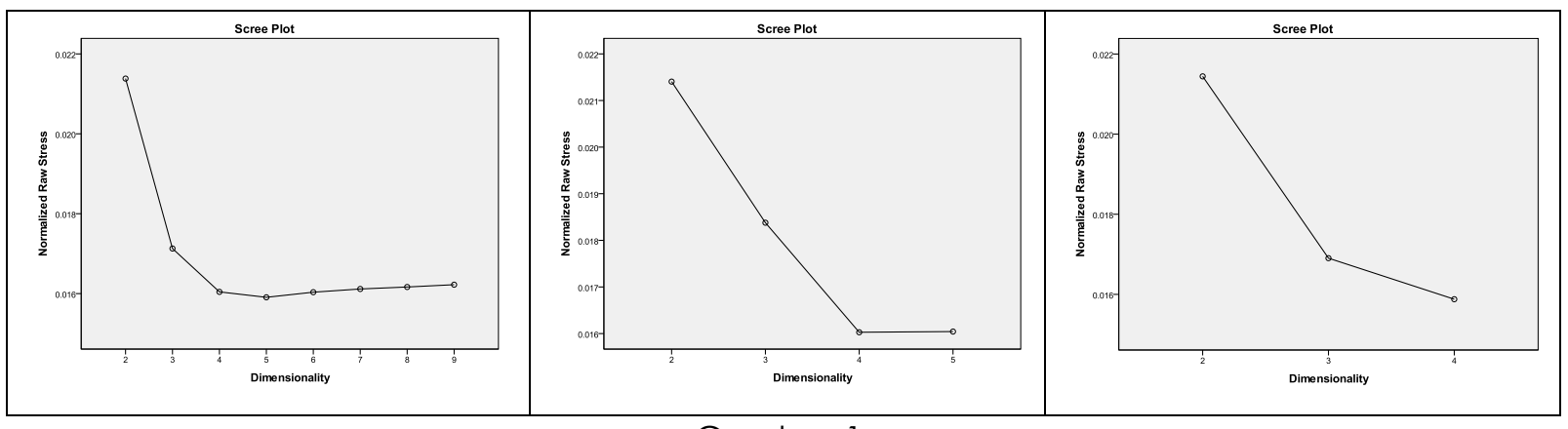

Gambar 1.

Hasil Pengujian Dimensi City Car di Makassar

Setelah menentukan dimensi tersebut, maka analisis positioning menggunakan MDS dapat dilakukan. Hasil dari analisis tersebut dapat dilihat pada gambar 2. Hasil dari analisis positioning dengan menggunakan MDS untuk konsumen pengguna city car menunjukkan bahwa positioning Mazda 2 berdekatan dengan Toyota Yaris dan Honda Jazz. Dapat dikatakan bahwa menurut konsumen pengguna city car pesaing terdekat Mazda 2 adalah Toyota Yaris dan Honda Jazz.Konsumen pengguna city car juga melihat positioning Daihatsu Sirion sangat berbeda dengan mobil-mobil lainnya. Pada hasil analisis ini, Daihatsu Sirion kembali berada jauh dan terpisah sendiri dengan mobil-mobil lainnya. Sedangkan untuk KIA RIO dan Hyundai Grand Avega juga sama-sama dianggap memiliki positioning yang sama di mata konsumen pengguna city car.

\section{Analisa Faktor}

Pendekatan yang digunakan untuk menentukan nama dimensi pada penelitian ini adalah dengan menghubungkan dimensi-dimensi tersebut dengan karakteristik spesial dari obyek penelitian dimana dalam hal ini karakteristik tersebut merupakan variabel-variabel tingkat kepentingan yang diperoleh melalui survey dengan hasil seperti di tabel 2. Analisis faktor dilakukan pada variabel tingkat kepentingan konsumen pengguna city car. Penentuan masuknya suatu variabel ke dimensi tertentu berdasarkan dari hasil analisis faktor. Pada analisis faktor yang dilakukan, variabel-variabel tersebut dikelompokkan ke dalam tiga kelompok yang nantinya menjadi dimensi dalam multidimensional scaling. Variabel-variabel tersebut kemudian dinilai kecocokannya untuk masuk pada dimensi yang mana. Variabelvariabel tersebut masuk pada suatu kelompok dimensi bila variabel tersebut memiliki nilai 
mutlak tertinggi di antara ketiga kelompok tersebut. Memang pada analisa positioning menggunakan dua dimensi berdasarkan hasil uji stress. Tetapi, untuk analisa faktor digunakan tiga dimensi karena terdapat 25 variabel dan supaya hasilnya lebih mengelompok berdasarkan kesesuaian. Hasil dari analisis faktor konsumen pengguna city car dapat dilihat pada tabel 5 berikut ini.

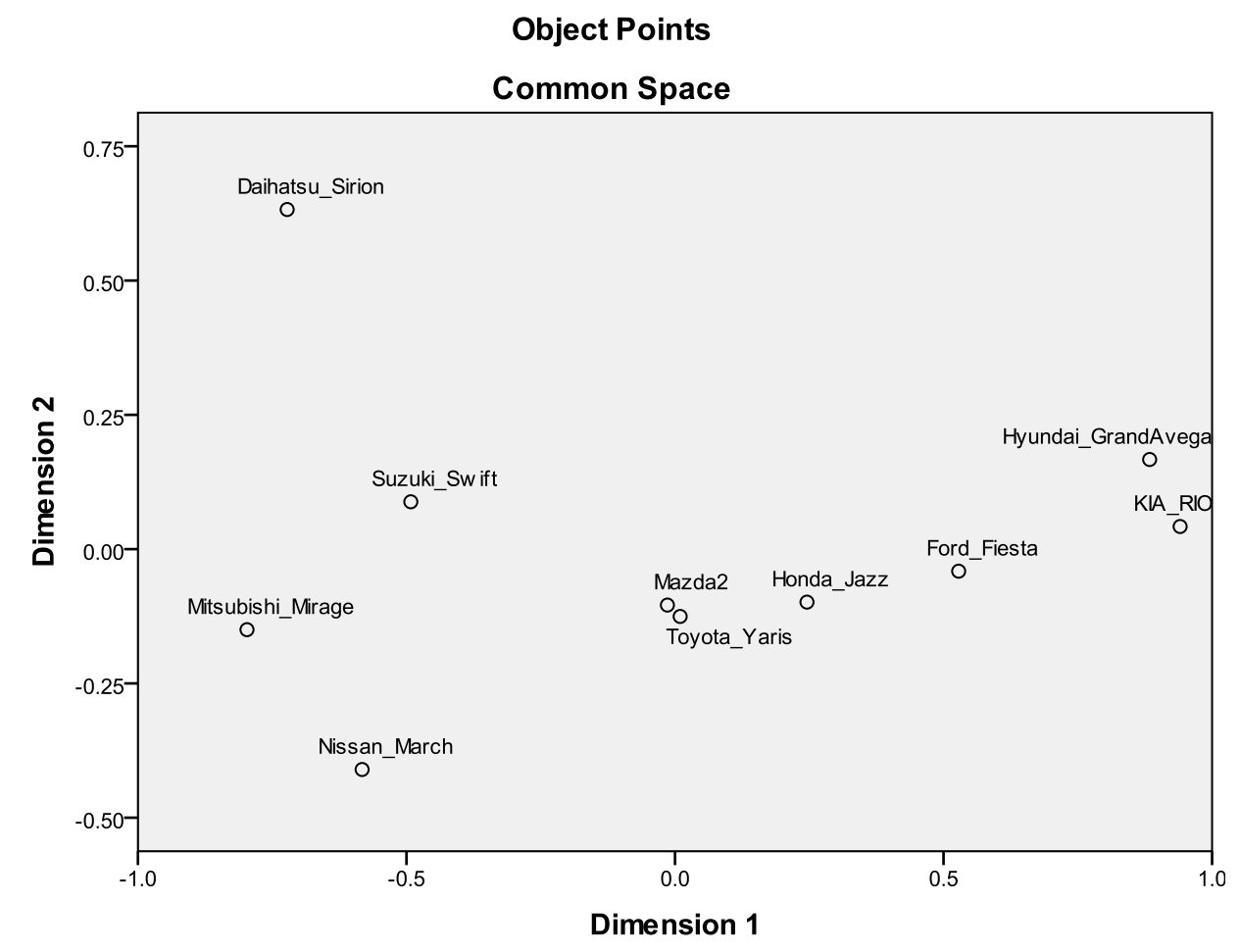

Gambar 2. Analisis Positioning City Car di Makassar

Selanjutnya dari hasil tersebut dikelompokkan sesuai dimensinya seperti pada tabel 6 . Berdasarkan analisis faktor yang dilakukan untuk variabel-variabel tingkat kepentingan konsumen pengguna city car, diperoleh hasil pembagian dimensi sebagai berikut:

1. Variabel-variabel di dimensi 1 adalah pilihan warna, ketersediaan produk di dealer resmi, pilihan cara pembayaran, kemudahan memesan produk, kemudahan membeli produk, kapasitas penumpang banyak, keamanan berkendara, brand image, promosi, dan showroom.

2. Variabel-variabel di dimensi 2 adalah model dan desain, mesin, fasilitas interior, perawatan, kenyamanan berkendara, bengkel, harga yang bersaing, bonus atau diskon, garansi, dan servis.

3. Variabel-variabel di dimensi 3 adalah ketersediaan suku cadang di bengkel resmi, bahan bakar irit, sales yang ramah dan informatif, kecepatan pelayanan, dan ketepatan pelayanan. 
Esti Dwi Rinawiyanti

Arbi Hadiyat

Hardi Yanto

Tabel 5.

Analisis Faktor untuk Penentuan Dimensi City Cardi Makassar

\begin{tabular}{|c|c|c|c|}
\hline \multirow{2}{*}{ Variabel-variabel } & \multicolumn{3}{|c|}{ Component } \\
\hline & 1 & 2 & 3 \\
\hline Model dan desain & 142 & .539 & 090 \\
\hline Mesin & 255 & ,438 & 300 \\
\hline Pilihan warna &, 501 & 145 & 051 \\
\hline Fasilitas interior & 356 & 669 &,- 042 \\
\hline Ketersediaan produk di dealer resmi & 667 & .131 & 392 \\
\hline Ketersediaan suku cadang di bengkel resmi & 097 & 129 & 664 \\
\hline Pilihan cara pembayaran &, 535 & 018 & 360 \\
\hline Kemudahan memesan produk & ,793 &,- 039 & 348 \\
\hline Kemudahan membeli produk &, 545 & 060 & 481 \\
\hline Penggunaan bahan bakar irit &,- 017 & 329 & ,446 \\
\hline Kapasitas penumpang banyak &, 515 & 081 & 352 \\
\hline Perawatan & 331 & 430 & 061 \\
\hline Kenyamanan berkendara &, 529 & 611 &,- 146 \\
\hline Keamanan berkendara &, 555 & 450 &,- 124 \\
\hline Sales yang ramah dan informative & 430 &,- 002 & 713 \\
\hline Kecepatan pelayanan & 062 & 050 & 925 \\
\hline Ketepatan pelayanan & 054 & 000 & 947 \\
\hline Brand Image & 665 & 186 &,- 099 \\
\hline Promosi & ,756 & 377 &,- 010 \\
\hline Showroom & ,726 & 336 & 146 \\
\hline Bengkel & 395 & 465 & 324 \\
\hline Harga yang bersaing & 182 & 751 & 011 \\
\hline Bonus atau diskon & 259 & 709 & 067 \\
\hline Garansi &,- 027 & 851 & 145 \\
\hline Servis &,- 117 & 830 &, 138 \\
\hline
\end{tabular}

Keterangan: Warna kuning menunjukkan variabel tersebut masuk ke dimensi mana

Berikutnya diberikan nama sesuai dengan hasil pengelompokan tersebut. Wawancara dilakukan dengan pemiliki dealer mobil di Makassar untuk mendapatkan nama yang sesuai. Hasilnya adalah diperoleh nama-nama untuk dimensi tersebut berdasarkan hasil analisis faktor yang telah dilakukan sebagai berikut:

- Dimensi 1: performa perusahaan pemegang merek 
- Dimensi 2: performa mobil yang ditawarkan

- Dimensi 3: penawaran promosi

Berdasarkan jumlah variabel di tiap dimensi dan digunakannya dua dimensi pada analisa positioning MDS, maka dimensi yang sesuai ialah performa perusahaan pemegang merek dan performa mobil yang ditawarkan.

Tabel 6.

Pengelompokan Variabel Konsumen Pengguna City Car di Makassar

\begin{tabular}{|c|c|}
\hline Dimensi & Variabel \\
\hline Dimensi 1 & Pilihan warna \\
\hline \multirow[t]{9}{*}{ (10 variabel) } & Ketersediaan produk di dealer resmi \\
\hline & Pilihan cara pembayaran \\
\hline & Kemudahan memesan produk \\
\hline & Kemudahan membeli produk \\
\hline & Kapasitas penumpang banyak \\
\hline & Keamanan berkendara \\
\hline & Brand image \\
\hline & Promosi \\
\hline & Showroom \\
\hline Dimensi 2 & Model dan desain \\
\hline \multirow[t]{9}{*}{ (10 variabel) } & Mesin \\
\hline & Fasilitas interior \\
\hline & Perawatan \\
\hline & Kenyamanan berkendara \\
\hline & Bengkel \\
\hline & Harga yang bersaing \\
\hline & Bonus atau diskon \\
\hline & Garansi \\
\hline & Servis \\
\hline Dimensi 3 & Ketersediaan suku cadang di bengkel resmi \\
\hline \multirow[t]{4}{*}{ (5 variabel) } & Penggunaan bahan bakar irit \\
\hline & Sales yang ramah dan informative \\
\hline & Kecepatan pelayanan \\
\hline & Ketepatan pelayanan \\
\hline
\end{tabular}




\section{Esti Dwi Rinawiyanti}

\section{Arbi Hadiyat}

Hardi Yanto

\section{PEMBAHASAN}

Berdasarkan hasil analisa faktor diperoleh dua nama untuk dimensi positioning MDS, yaitu performa perusahaan pemegang merek dan performa mobil yang ditawarkan. Dengan demikian dari dua dimensi tersebut empat city car yang posisinya berdekatan ialah Honda Jazz, Toyota Yaris, dan Mazda 2. Temuan ini mendukung hasil penelitian Tiara dkk (2014), walaupun sedikit berbeda, yang menyatakan bahwa posisi Honda Jazz berdekatan dengan Toyota Yaris, Swift, dan Picanto. Data sekunder juga menunjang hal tersebut bahwa selama tiga tahun berturutan dari 2008-2010 pasar city car di Indonesia dikuasai oleh Honda Jazz, Toyota Yaris dan Swift (Putu Agus, 2011). Selain itu, ketiga merek city car tersebut juga mendapatkan Top Brand Index Kategori Otomotif Mobil City Car-Mini MPV dari tahun 2008 sampai 2010. Selama masa tersebut Mazda 2 tidak termasuk karena Mazda 2 baru masuk ke Indonesia di akhir tahun 2009 (Okezone, 2013). Walaupun demikian, berdasarkan data dari Gaikindo, selama Januari-November tahun 2010 Mazda 2 berada di peringkat keempat merek city car yang mendominasi pasarcity car di Indonesia (Oto Detik, 2010). Pada penelitian ini posisi Suzuki Swift agak berjauhan dari Honda Jazz, Toyota Yaris, dan Mazda 2. Penelitian Ni Luh (2011) juga menyatakan bahwa posisi Toyota Yaris berdekatan dengan Honda Jazz, walaupun Toyota Yaris mendapatkan preferensi tertinggi dari konsumen di kota Semarang. Hasil dari penelitian Hardianto (2006) juga menunjukkan hal yang sama. Dengan demikian dapat dikatakan bahwa posisi Honda Jazz sangat berdekatan dengan Toyota Yaris. Hal ini harus dipertimbangkan baik-baik oleh produsen dan dealer mobil Honda dan Toyota dalam merancang strategi pemasaran untuk kedua merek tersebut.

Yang cukup menarik dari hasil penelitian ini adalah posisi Ford Fiesta yang lebih jauh sedikit dari posisi Honda Jazz. Dari hasil penelitian Tiara dkk (2014) Ford Fiesta unggul di dimensi kedua dengan atribut-atribut yang membentuk dimensi antara lain: mesin yang halus, akselerasi sangat reponsif, kualitas bahan pelat bodi yang baik, fitur mobil berteknologi tinggi, dan ketersediaan suku cadang yang mudah didapat. Menurut data dari internet, sejak masuk ke Indonesia di tahun 2010 sampai Juli 2013, penjualan Ford Fiesta berhasil menguasai 10 persen pangsa pasar city car di Indonesia (Marketing Communication, 2013).

\section{KESIMPULAN}

Berdasarkan hasil pengumpulan data, pengolahan data, dan analisa data, maka dapat diambil kesimpulan sebagai berikut. Dari analisa deskriptif diperoleh gambaran bahwa mayoritas konsumen pengguna city car di kota Makassar adalah laki-laki, berusia 21-39 
tahun, sudah bekerja, dan pendapatan per bulan lebih dari Rp 6 juta. Tiga variabel kepentingan yang memiliki nilai rata-rata tertinggi untuk konsumen penggunacity car adalah keamanan berkendara, kenyamanan berkendara, dan garansi.Hasil dari analisis positioning dengan menggunakan MDS menunjukkan bahwa keempat city car yang posisinya berdekatan Mazda 2, Toyota Yaris, Honda Jazz, dan Ford Fiesta. Dengan demikian pesaing terdekat Honda Jazz ialah Toyota Yaris, disusul Mazda 2 dan kemudian Ford Fiesta. Posisi Daihatsu Sirion berada jauh dan terpisah sendiri dengan mobil-mobil lainnya, sedangkan untuk KIA RIO dan Hyundai Grand Avega juga sama-sama dianggap memiliki positioning yang sama menurut persepsi konsumen pengguna city car.Pemberian nama dengan menggunakan analisa faktor menghasilkan tiga dimensi, yaitu performa perusahaan pemegang merek, performa mobil yang ditawarkan, dan penawaran promosi.

\section{DAFTAR PUSTAKA}

Cochran, W. 1977. Sampling Techniques (3rd ed.). New York: John Wiley and Sons, Inc.

Dapur Pacu. 2014. Makassar Bakal Macet Seperti Jakarta. http://dapurpacu.com/221716/makassar-bakal-macet-seperti-jakarta/26 Nov 2014 (diakses 30 Juli 2015).

Ginanjar, I. 2008. Aplikasi Multidimensional Scaling (MDS) untuk Peningkatan Pelayanan Proses Belajar Mengajar (PBM). Staf Pengajar Jurusan Statistika FMIPA UNPAD, Bandung.

Hair, Jr., J. E., Black, W. C., Babin, B. J., \& Anderson, E. 2010. Multivariate Data Analysis. 7th Edition, Upper Saddle River, New Jersey: Prentice-Hall.

Hardianto, F. 2006. Analisis Positioning Produk Mobil mini MPV (Studi: Honda Jazz, Toyota Yaris, Suzuki Swift, Chevrolet Aveo) Berdasarkan Persepsi Konsumen di Yogyakarta. Skripsi. Universitas Muhammadiyah Yogyakarta.

Kompas. 2015. Pertumbuhan Ekonomi Makassar Tinggi Tapi Infrastruktur Mandek. http://properti.kompas.com/read/2015/06/10/220000121/Pertumbuhan.Ekonomi.Maka ssar.Tinggi.tapi.Infrastruktur.Mandek 10 Juni 2015 (diakses 30 Juli 2015).

Kotler, P. \& Armstrong, G. 2012. Principles of Marketing, Fourteenth Edition, New Jersey: Pearson Education, Inc.

Liputan 6. 2014. Mana Yang Jadi Pilihan Orang Indonesia: MPV atau City Car.http://otomotif.liputan6.com/read/2071795/mana-yang-jadi-pilihan-orangindonesia-mobil-mpv-atau-city-car (diakses 30 Juli 2015).

Marketing Communication (MIX). 2013. Terjual 17.500 Unit, Ford Fiesta Kuasai 10\% Pangsa Pasar. http://mix.co.id/headline/terjual-17-500-unit-ford-fiesta-kuasai-10-pangsa-pasarhatchback (diakses 05 Juli 2017). 


\section{Esti Dwi Rinawiyanti}

\section{Arbi Hadiyat}

\section{Hardi Yanto}

Ni Luh Desy Ayucista Damayanti, Yudi Pramudiana. 2011. Analisis Positioning Bauran Pemasaran Merek Mobil Jenis Hatchback Car Berdasarkan Persepsi Konsumen di Kota Semarang. Tugas Akhir. Universitas Telkom.

Okezone. 2013.2 Buka Mazda2,

http://news.okezone.com/read/2013/11/08/52/893926/muka-baru-mazda2/large (diakses 05 Juli 2017).

Otoasia. 2015. Ini Lima City Car Terlaris di Indonesia. http://www.otosia.com/berita/ini-limacity-car-terlaris-di-indonesia.html (diakses 30 Juli 2015).

Oto Detik. 2010. Setelah City Car, Hatchback Finish di Urutan Kedua. https://oto.detik.com/berita/1524814/setelah-city-car-hatchback-finish-di-urutankedua (diakses 05 Juli 2017).

Otomotif Bisnis. 2015. Pertumbuhan Ekonomi Melambat Berharap pada City Car. http://otomotif.bisnis.com/read/20150122/46/394127/pertumbuhan-ekonomimelambat-berharap-pada-city-car (diakses 30 Juli 2015).

Putu Agus Sumahajaya. 2011. Analisa Pengaruh Ekuitas Merek Terhadap Minat Beli Mobil Honda Jazz di Surabaya. Skripsi. Universitas Pembangunan Nasional 'Veteran' Jawa Timur.

Rakyat Sulsel. 2013. Prospek Penjualan Mobil Bakal Tumbuh Pesat.http://rakyatsulsel.com/prospek-penjualan-mobil-bakal-tumbuh-pesat.html (diakses 30 Juli 2015).

RazaRabbani, M. \& Nabi, M.K. 2013. Application of Multidimensional Scaling Model towards Positioning of Commercial Banks: A Case Study of Public Sector v/s Private Sector Banks. Research Journal of Social Science and Management 3 (2): 54-61.

Tiara, A.E.R., Iriani, Sri S.2014. Analisis positioning berdasarkan persepsi atribut produk. Jurnal Ilmu Manajemen 2 (1): 254-265. 